\title{
THE FIRST PRINTING PRESS IN MínNesota.
}

\section{BY J. FLETCHER Williams, of st. PALL.}

The writer of the newspaper article on the first printing press in Iowa, \&c., published in the January number of the AnNaLs, has fallen into some errors which I feel called on to correct. Being now engaged, at the request of the Editorial Association of this State, in compiling a history of the press of Minnesota, I think the statements I make can be relied on as correct.

The press which James M. 'Goodhue brought to St. Paul was indeed the one formerly used to print the Dubuque Visitor, and beyond doubt the first printing press in Iowa, but it was not hauled to St. Paul on an ox-team in the winter, as stated. He came up with his press and materials on a steamboat, and landed here on April 18, 1849. Just ten days afterwards he issued the first paper ever printed in Minnesota, the "Minnesota Pioneer."

The Pioneer press was not sold to a Dakota publisher as stated. It was sold to a little paper published in a town a few miles above St. Paul,-re-sold shortly afterward to another printer in Northern Minnesota, and finally, after eighteen years of service in Minnesota, was, two years since, sold to the Siminton Brothers, who established in 1867, and still publish the Herald at the thriving town of Sauk Centre.

One of the present owners of the veteran press writes that it is good as new still, and accompanying it are the original cabinets and cases that Goodhue brought to Minnesota with him twenty years ago. The Minnesota Historical Society has the promise of the old press when its owners can spare it, and it will one day be truly a relic for an antiquarian collection.

The press which was sold and shipped to the paper in $\mathrm{Da}$ kota, was another press used in the Pioneer office, and was for some time supposed to be the original press of Goodhue, until a paragraph of inquiry set afloat by the writer of this article, produced evidence that the " historic" press was still 
safe and sound in the office of the Sauk Centre Herald. This fact will no doubt be read with pleasure by your readers, who have been bewailing its supposed sad fate, as recorded in the January number of the ANNALs.

HISTORY OF JACKSON COUNTY, IOWA.
BY F. 8NYDER, EX-EDITOR JACKSON COUNTY SENTINEL.

[Continued from page 50.]

Since writing the brief sketch of Jackson County, published in the January number of the Ansals, I have concluded that a more particular description of that county would not be entirely devoid of interest.

MAQUOKETA CITY

Is situated in a beautiful prairie, not far from the junction of the north and south forks of the Maquoketa River, two miles from the north line of Clinton County. Though without a navigable river or railroad, it is one of the best business points in Iowa. Perhaps one-third of the Clinton County farmers, besides a large number of the citizens of Jackson County necessarily have to pass through Maquoketa City to enter the large body of woodland known as the Maquoketa timber, the largest body of timber in the State.

Almost any pleasant winter day fifty or more teams, hauling timber, may be seen at one view passing between the city and the bridge over South Fork.

The principal publications of Maquoketa City for several years past have been the Excelsior and the Sentinel. Among the editors of the former' were W. S. 'Eddy, Esq., Col. J. J. Woods, W. F. MeCarron, and Peter Moriarty. Of the latter, W. C. Swigart \& Brother, Walworth \& Tilney, G. W. Hunt, and the writer.

On March, 1866, G. W. Hunt removed the old Sentinel office to LeClaire, Iowa, where he commenced the publication of the Scott County Register, on the 17th day of April of that year. Mr. W. C. Swigart purchased a new office last fall and is now publishing the Jackson Sentinel. 
Copyright of Annals of Iowa is the property of State of Iowa, by \& through the State Historical Society of Iowa and its content may not be copied or emailed to multiple sites or posted to a listserv without the copyright holder's express written permission. However, users may print, download, or email articles for individual use. 